\title{
Civil Society Participation in Efforts to Prevent the Spread COVID-19
}

\author{
Khusnul Prasetyo * \& Lukman Arif \\ Public Administration, Faculty of Social and Political Sciences, \\ Universitas Pembangunan Nasional "Veteran” East Java, Indonesia \\ Received: 09 August 2020; Reviewed: 25 August 2020; Accepted: 23 March 2021 \\ ${ }^{*}$ Coresponding Email: khusnulprasetvo4@gmail.com
}

\begin{abstract}
This study aims to describe civil society participation in efforts to prevent the spread of COVID-19 in Sidoklumpuk Village, Sidoarjo Sub-District, Sidoarjo Regency and the obstacles faced. The method used was descriptive qualitative with data collection techniques through interviews, observation, documentation, and literature review. The results of this study indicate that civil society participation was carried out in mutual cooperation which was divided into four task forces including the Wani Ngandani Task Force which tried to educate residents to implement health protocols, while the Wani Jogo Task Force was tasked with limiting the mobility of residents with a one gate system. There was also the Wani Sehat Task Force which functions to ensure the availability of a place to wash hands in front of the house and a Wani Sejahtera Task Force which identified the food needs of Probable (ODP), Confirmation (PDP), Suspect (OTG) patients, and confirms outpatient care with predetermined criteria. Several obstacles were encountered such as lack of funds and low public awareness. The formation of Kampung Tangguh Semeru through the COVID-19 Prevention Task Force in Sidoklumpuk Village was a concrete form of civil society participation at the grassroots level with a partnership model.
\end{abstract}

Keywords: Civil Society Participation; Prevent the Spread of COVID-19; Kampung Tangguh.

How to Cite: Prasetyo, K., \& Arif, L. (2021). Civil Society Participation in Efforts to Prevent the Spread COVID-19. Jurnal Administrasi Publik (Public Administration Journal). 11(1):22-31. 


\section{INTRODUCTION}

At the end of 2019 the world was shocked by the new emerging infectious disease in China which was caused by the Coronavirus Disease (COVID-19). The beginning of the Coronavirus was classified as "Public Helath Emergency of International Concern", by the World Health Organization (WHO), namely on January 30, 2020. WHO designated the name of the Coronavirus as SARS-CoV-2, on February 11, 2020 (WHO, 2020).

For this incident, WHO as the World Health Organization assessed the risk due to the virus in the high category at the global level and determined the status of Public Health Emergency of International Concern (PHEIC) since January 30, 2020. WHO also issued temporary guidelines in accordance with the instruments of the International Health Regulation 2005 (IHR 2005) such as surveillance and response guidelines, laboratory diagnosis, infection prevention and control, clinical management, care for patients with suspected COVID-19, risk communication, and community empowerment. It is expected that these guidelines can be adopted by countries in the world in an effort to prevent the spread of COVID-19 (Kompas.com, 2020c).

The first cases of COVID-19 were reported in Indonesia on March 2, 2020, totaling two cases. On August 1, 2020 data indicate that there were 108,376 confirmed cases and 5,131 deaths (Johns Hopkins University (JHU), 2020). Meanwhile, the death rate or case fatality rate (CFR) due to COVID-19 in Indonesia was 5.15 percent (Kompas.com, 2020a).

Various policies have been issued by the central government in an effort to anticipate the prevention of COVID-19, including calls for people to implement Health Protocols such as social distancing, physical distancing, using masks, washing their hands using soap or hand sanitizer diligently, and self-isolation and stay away from the crowd. In addition, the central government also issued Communication Protocols, Border Control Protocols, Educational Area Protocols and Public Areas and Transportation Protocols (Ministry of Health of the Republic of Indonesia, 2020). The high number of COVID-19 spread in several regions in Indonesia has led the government to also issue a Large-Scale Social Restriction (PSBB) policy (National Disaster Management Agency, 2020).

Even though during the pandemic, the central government provided norms, standards, guidelines, and criteria in handling COVID-19, the problems faced actually rests on the local government (Ariyanto, 2020). In preventing the spread of COVID-19, the Sidoarjo Regency Government (Pemkab Sidoarjo), East Java seeked to take curative, preventive to promotive measures, including education on health protocols so that people really practice Clean and Healthy Behavior (PHBS), distribution of masks and spraying disinfectants. at market booths, one of which is the Larangan Market (Sidoarjo Regency Government, 2020b). As of July 21, 2020 , the percentage of positive cures for COVID-19 in Sidoarjo Regency has reached 43 percent or almost half of the number of people confirmed with COVID-19 have been declared cured Currently, the Sidoarjo Regency Government continued to strive to resolve and reduce the spread of COVID-19 by preaching 'Fight the COVID-19 Pandemic' to the public (Sidoarjo Regency Government, 2020a).

The three most fundamental changes in people's behavior when COVID-19 has plagued Indonesia are staying at home, washing hands frequently, and obeying social distancing even though there are some that violate the result of the low degree of public trust and compliance with the government (Mas'udi \& Winanti, 2020). In the early phases of the COVID-19 pandemic, it was clear that there was skepticism from the government that underestimated the coronavirus 
(Viva.co.id, 2020), they even considered that the flu that commonly affects Indonesian citizens actually has a higher mortality rate than the coronavirus. The statement was conveyed by the Minister of Health, dr. Terawan Agus Putranto (Kompas.com, 2020b).

As a result, people were also getting away from the perception of risk caused by a pandemic. Coupled with the relatively low awareness, even though the government's appeal or recommendation in the form of a health protocol has been announced (Djalante et al., 2020).

The various efforts that have been made by the Central Government and Sidoarjo Regency Government are certainly meaningless without the role, contribution and participation of the civil society to fight the COVID-19 pandemic. To optimize the role of the civil society, the Sidoarjo Regency Government together with the Sidoarjo Police, the Kodim 0816 Sidoarjo and the Village Government launched Kampung Tangguh Semeru (Healthy, Safe, Orderly and Rukun). It was done as an effort to prevent the spread of COVID-19 at the village level. The formation of Kampung Tangguh Semeru is a program initiated by the East Java Regional Police to optimize civil society participation and build civil society discipline, in this case at the village level, particularly in preventing the spread of COVID-19 (Purnomo, 2020).

Sidoklumpuk Village is actively participating in the response to the COVID19 pandemic. Through the initiative of the residents, this village is trying to form a COVID-19 prevention task force. In addition to trying to tackle the spread of COVID-19, the task force also anticipates and overcomes the impacts caused by the COVID-19 pandemic, such as unemployment, destruction of supply-side chains and an increase in poverty (Suryahadi et al., 2020).

According to Sastropoetro (1986), participation is defined as the involvement or participation of a person either individually or in groups in a particular activity. Meanwhile, according to Pasaribu (2012), participation is a form of mental / thought and emotional involvement or a person's feelings in a group situation that encourages him to contribute to the group in an effort to achieve goals and to take responsibility for the business concerned.

$$
\text { According to Dusseldorp in }
$$

Mardikanto, Totok \& Soebiato (2012) identify forms of participatory activities carried out by each civil society, which can include: becoming a member of community groups; involve yourself in group discussion activities; involve oneself in organizational activities to mobilize the participation of other communities; mobilizing community resources; take part in the decision-making process and take advantage of the results achieved from community activities.

According to Sherry R Arnstein in Wijaksono (2013) dividing 8 levels of civil society participation. The levels of participation from lowest to highest are as follows: 1) Manipulation. It can be interpreted that there is relatively no communication, let alone dialogue; the real objective is not to involve the civil society in program planning and implementation but to educate participants (the civil society did not know the purpose at all, but was present in the forum); 2) therapy. At this level there is communication but it is limited. Initiatives come from government and are only one-way and have very little chance of bringing about change; 3) information. At this level, communication has started to occur a lot but it is still oneway and there is no means of reciprocity. Information has been provided to the civil society but the civil society has not been given the opportunity to provide feedback; 4) consultation. At this level communication is two-way, but still ritual participation. There has been aspiration gathering, rules for submitting proposals and hopes that the people's aspirations will be heard, but there is no guarantee whether 
these aspirations will be implemented; 5) placation. At this level, communication has gone well, the civil society is welcomed to provide suggestions or plan proposed activities. However, the government still retains the authority to assess the feasibility and existence of these proposals. The top three ladders were categorized as the true form of participation in which the civil society has influence in the decisionmaking process. 6) partnership. At this level, government and society are equal partners. Power has been granted and there have been negotiations between communities and power holders, both in terms of planning, implementation, and monitoring and evaluation. 7) delegated power. It means that the government gives authority to the civil society to formulate planning, implementation, monitoring and evaluation processes, so that the civil society has clear power and is fully responsible for the success of the program. 8) Citizen control. This is the highest level, where the civil society fully manages various activities for their own interests, which are mutually agreed upon, and without government interference.

Previous study conducted by Mohammad Mulyadi (2020) with the title "Civil society Participation in Handling the Spread of COVID-19" suggested that civil society participation is the main key to success in preventing the spread of the COVID-19 outbreak. Social distancing and physical distancing were applied to cut the chain of spreading the virus. Some people have consciously followed this social restriction mechanism, but some have not participated. This article examined public participation in preventing the spread of the COVID-19 pandemic in Indonesia (Mulyadi, 2020).

Study conducted by Mohammad Mulyadi was still very universal and had not been able to describe the specific role of society at the grass roots level. Therefore, it is necessary to explore more about civil society participation at the $R T$
(Neighborhood Association), $\quad R W$ (Hamlet/Citizens Association), and subdistrict levels.

Therefore, it is what then underlies the author to conduct study that focused on describing civil society participation in efforts to prevent the spread of COVID-19 in Sidoklumpuk Village, Sidoarjo Sub-District, Sidoarjo Regency and the obstacles faced. This study was conducted during the period of July 2020 with several informants including: 1) Sidoklumpuk Village Headman; 2) Secretary of Sidoklumpuk Village; 3) Head of the Empowerment of Family Welfare (PKK) Sidoklumpuk Village; 4) Chairperson of team work (Pokja) 3, PKK of Sidoklumpuk Village; 5) Chairperson of team work 4, PKK of Sidoklumpuk Village; 6) Head of RW 02, Sidoklumpuk Village; and 7) Head of $R T 15, R W 05$, Sidoklumpuk Village.

\section{RESEARCH METHOD}

This study used a qualitative approach based on the post-positivism philosophy, which was used to examine the conditions of natural objects (Sugiyono, 2019). This method was also called an artistic method, because the research process was more artistic (less patterned), and was called an interpretive method because the research data were more concerned with the interpretation of the data found in the field. Descriptive in nature because it described or took pictures of what happens to the object under study. Descriptive research was conducted to determine the value of the independent variable, either one or more variables, without making comparisons or linking between variables (Kuswana, 2011). The objective of descriptive research is to make a systematic, factual, and accurate description of the facts and characteristics of a particular population or area (Aslichati et al., 2017).

Research data collection was carried out through: 1) participatory observation in which the researcher was involved in the daily activities of the object being observed 
for approximately one month; 2) semistructured interviews which were also included in the in-dept interview category, which in practice was more flexible than structured interviews; and 3) documentation which was a record of past events in the form of pictures, works, notes, regulations, policies and so on (Sugiyono, 2019). In data collection, primary data sources were used directly from informants and secondary sources from books, news, scientific articles and relevant laws and regulations. Determination of informants was done by using snowball sampling technique, which was a method of sampling data sources, which at first was based a little on subjects who really master the problem, and then gradually became large because the main subject recommended the next subjects who were considered to have data and information. more complete.

The data analysis technique used an interactive model from Miles, Huberman \& Saldana (2014) which was carried out in several stages, starting from data collection, data condensation, data display, to conclusion drawing or verification.

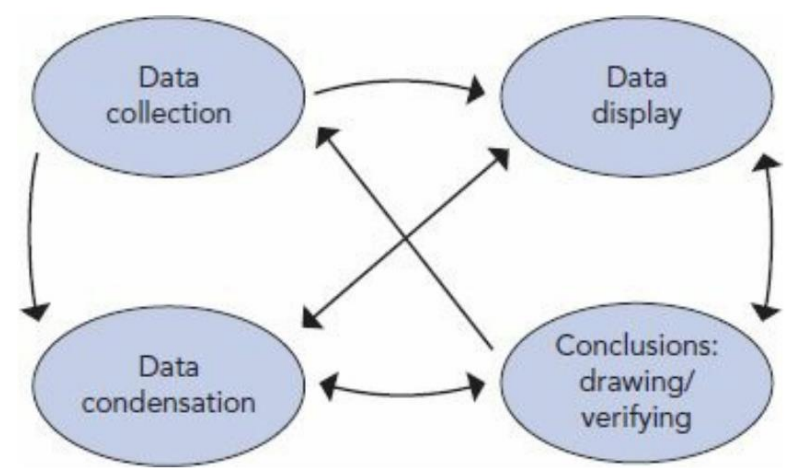

Figure 1. Components of Data Analysis: Interactive Model

Source: Miles, Huberman \& Saldana (2014)

\section{RESULTS AND DISCUSSION Civil Society Participation in Preventing the Spread of COVID-19}

In an effort to prevent the spread of COVID-19, civil society participation was one of the keys to breaking the chain of the spread of COVID-19 so that it can be controlled (Mulyadi, 2020). Government appeals such as the application of social distancing and physical distancing was meaningless if the civil society ignored these recommendations. Therefore there needed to be an earthing effort and the massiveness of the government's appeal to be conveyed to all levels of society. Not only by the government alone but starting from the civil society itself.

In Sidoklumpuk Village, this agent of change was the driving force, trying to ensure that people were awakened to comply with health protocols and implement a Clean and Healthy Lifestyle (PHBS). The agent of change consisted of various elements of society in Sidoklumpuk Village, consisting of the Sidoklumpuk Village Headman, Village Officers, Empowerment of Family Welfare, Religious Leaders, Community Leaders, Youth Organizations, to the Head as well as the Management of Neighborhood Association (RT) and Hamlet/Citizens Association (RW). All of these elements were moving together working together to reduce the spread of COVID-19.

The form of civil society participation in the context of preventing the spread of COVID-19 in Sidoklumpuk Village is to become part of and involve yourself with members of community groups and conduct group discussion activities and involve yourself in organizational activities to mobilize other civil society participation. The group or organization in question was the COVID-19 Prevention Task Force as a realization of Kampung Tangguh Semeru.

The level of civil society participation in Sidoklumpuk Village in the context of preventing COVID-19 was at the partnership level. At this level, the government (Task Force for the Acceleration of Handling COVID-19 in Sidoarjo Regency) and the civil society (forming the COVID-19 Prevention Task Force) were equal partners by delegating power and there had been negotiations between the civil society and the holders of 
power, in this case the power was in the form of implementation. Considering the government's limitations in deeper intervention at the grass roots level.

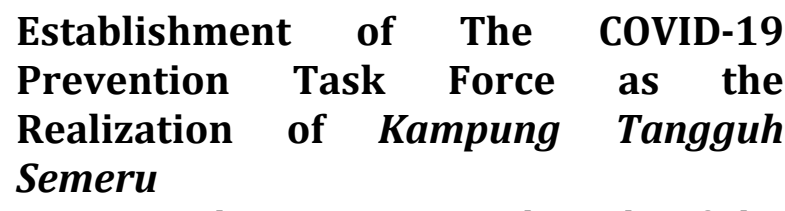

In order to optimize the role of the civil society, the Sidoarjo Regency Government and the Sidoarjo Police, Kodim 0816 Sidoarjo launched the Kampung Tangguh Semeru program as an effort to prevent the spread of COVID-19 at the village / sub-district level. The initiator of Kampung Tangguh Semeru was the East Java Regional Police Chief to build civil society discipline, in order to prevent the spread of COVID-19 (Surabaya Morning, 2020).

Sidoklumpuk Village made this happen by forming a COVID-19 Prevention Task Force. The task force was then divided into four task forces which had different tasks. The task force consisted of various elements, both the Sidoklumpuk Village Headman, Religious Figures, Empowerment of Family Welfare (PKK), RT and $R W$.

\section{Wani Jogo Task Force (Dare to Watch)}

In Sidoklumpuk Village, the Wani Jogo Task Force had the task of limiting and recording residents and vehicles coming and going (one gate system). Then make a schedule to guard the village, and monitor and ensure that residents who were independently isolated did not leave the home environment except for the needs of health facilities, maintain and ensure that all residents, especially the elderly, disabled, and children were protected from the risk of transmission, ensure social and security activities were carried out working together, ensuring the implementation of health protocols (physical distancing, wearing masks, washing hands with soap), and spraying disinfectants.
In order to facilitate residents who have to be isolated and indicated as having been exposed to COVID-19, the COVID-19 Prevention Task Force in Sidoklumpuk Village has provided a special place for selfquarantine for residents. The selfquarantine place was a former school building that wass no longer in use. Because it was not used, residents had taken the initiative to use it as an independent quarantine place, considering that residents' homes or village offices were also not possible to be used as independent quarantine places.

\section{Wani Ngandani Task Force (Dare to Tell/Advise)}

Wani Ngandani Task Force in Sidoklumpuk Village was tasked with providing education to residents regarding the importance of health protocols by implementing 3M (washing hands with masks and maintaining distance). It was done in two ways. The first way was to remind residents directly by reprimanding them if they were caught not complying with health protocols, such as not wearing masks, crowding and not implementing social distancing. The second way was to provide understanding to residents online through the WhatsApp group, besides that the WhatsApp group also functions as a means of COVID-19 information from urban villages and puskesmas.

Wani Ngandani Task Force also coordinated and reported the progress of the handling of Probable (ODP), Confirmation (PDP), Suspect (OTG) and positive confirmed patients to the Sidoklumpuk Village Headman and Community Health Center Midwives so that they can be followed up if they feel that further treatment was needed.

\section{Wani Sehat Task Force (Brave Healthy) \\ Wani Sehat Task Force has a function to ensure residents provide a place to wash their hands with running water and soap or hand sanitizer in front of the house.}


Especially for the Neighborhood Association Headman, it is mandatory to remember that their role is at the forefront of community services at the bottom.

Monitored Probable (ODP), Confirmation (PDP), Suspect (OTG) patients, and those who were confirmed positive based on directions from the Task Force for the Acceleration of Handling COVID-19 in Sidoarjo Regency. Then collect data on residents who were in close contact with patients, and were tasked with reporting to the Public Health Centre, village and sub-district if any of their residents had symptoms of COVID-19.

In an interview with the Sidoklumpuk Village Headman, he said that:

"After the direction for the formation of Kampung Tangguh from the Sidoarjo regency, I, as the Sidoklumpuk Village Headman, immediately conveyed to the village apparatus and several elements of society to form a COVID-19 prevention task force and its structure, such as Wani Jogo, Wani Ngandani, Wani Sehat and Wani Sejahtera. Each task force had different roles and functions. Everything works independently".

\section{Wani Sejahtera Task Force (Dare to Be Prosperous)}

It identified the food needs of Probable (ODP), Confirmation (PDP), Suspect (OTG) patients, and confirm outpatient care with predetermined criteria. Then identified the affected people who were unable, and make efforts to deal with the affected people in mutual cooperation, and ensure that government social assistance reached the recipient.

Based on the results of the interviews, to date, Sidoklumpuk Village had received assistance from various parties, including government agencies, private institutions and campus agencies such as masks, hand sanitizers, basic necessities, touchless hand sanitizers and social assistance from
Sidoarjo Regency Government. East Java Provincial Government and Central Government in cash. Wani Sejahtera Task Force was conducting data collection on residents affected by COVID-19, victims of termination of employment (PHK) and poor people by providing standardization of feasibility, ranging from very needy, needy, sufficiently needy to those who do not yet need it.

In addition, Wani Sejahtera Task Force in Sidoklumpuk Village was at the forefront of food security by ensuring that residents who were isolated independently at home and in self-quarantine were met with their needs. However, Wani Sejahtera Task Force was greatly helped by the spirit of mutual cooperation, working hand in hand with each other and a sense of helping the residents in Sidoklumpuk Village.

After there were 22 positive cases of COVID-19 in Sidoklumpuk Village, 9 people in $R T 15, R W 05$ were forced to be selfquarantined including the toddlers in them, local residents immediately volunteered to buy milk, eucalyptus oil, powder, fruit, vegetables and others. Even the Head of $R T$ $15, R W 05$ toured the participation of residents to make donations to the residents who were independently quarantined. The mutual cooperation carried out by residents of $R T 15, R W 05$ was also carried out in $R T 02$, RW 01 due to a positive case and forced two families to isolate themselves at home.

In an interview with the Chairperson of Team Work (Pokja) 3, Empowerment of Family Welfare (PKK), Sidoklumpuk Village, regarding the implementation of the COVID-19 Prevention Task Force, he said that:

"We socialize through the Whatsapp group of Neighborhood Association, even any information also through the Whatsapp group. In Sidoklumpuk Village, there were several Whatsapp groups. There were Whatsapp groups for the Neighborhood Association Headman and Whatsapp groups for 
the Wife of the Neighborhood Association Headman (special for women and special for men). There is a group for team work group cadres and health cadres, religious leaders, and community leaders".

"Even the Sidoklumpuk Village Headman himself goes around the neighborhood associations area almost every day, and even then the Neighborhood Association Headman does not know that the village headman goes around every day, whether it's morning, noon, evening, even night. Sometimes at 1 or 2 o'clock, that night greeted Pak RT through the Whatsapp group. So it can be seen who the Neighborhood Association Headman answered the message and who really takes care of the environment. That is the greatness of my village headman. The Wife of Sidoklumpuk Village Headman is also like that, he has a very high social sense".

\section{Constraints Faced by the COVID-19 Prevention Task Force}

Even though the maximum contribution and efforts have been made by the people of Sidoklumpuk, especially the COVID-19 prevention Task Force, it does not mean that the journey will not encounter obstacles or obstacles. The obstacles faced by the COVID-19 prevention Task Force include the lack of funding from the government for operationalizing COVID-19 prevention activities. Even though the intake of funds is very minimal, this does not diminish the spirit of the COVID-19 Prevention Task Force to break the chain of the spread of COVID-19 in Sidoklumpuk Village. So far, the need for funds has been supported by the civil society itself through swadaya (joint venture) and assisted by donors who are willing and sincere to provide as sustenance for the sake of preventing COVID-19.
Another obstacle faced by the COVID19 Prevention Task Force, namely the low awareness of the public by assuming the coronavirus did not exist, was only a conspiracy and was in the interests of the capitalists as if it was deliberately made up. Even though education and outreach had been carried out on a massive scale, there were still people who ignore it and ignore the various calls by the COVID-19 Prevention Task Force. A form of neglect of appeals such as violation of health protocols.

In an interview with the Chairperson of the Empowerment of Family Welfare, Sidoklumpuk Village, regarding the obstacles he said that:

"The funds are really minimal, most of them is self-help, for consumption that is also self-supporting, we / all citizens contribute as much as we can, sometimes we also try to ask for donations for the residents of Sidoklumpuk whose economy is well established".

\section{CONCLUSION}

Civil society participation in Sidoklumpuk Village was marked by the formation of Kampung Tangguh Semeru which was realized through the formation of the COVID-19 Prevention Task Force. The form of civil society participation in preventing the spread of COVID-19 in Sidoklumpuk Village is to become part of and involve oneself with members of community groups and conduct group discussion activities and involve themselves in organizational activities to mobilize other civil society participation. The group or organization in question was the COVID-19 Prevention Task Force as a realization of Kampung Tangguh Semeru.

The level of civil society participation in Kelurahan Sidoklumpuk in the context of preventing COVID-19 was at the partnership level. At this level, the government (Task Force for the Acceleration of Handling COVID-19 in 
Sidoarjo Regency) and the civil society (forming the COVID-19 Prevention Task Force) were equal partners by delegating power, this power was in the form of implementation given the government's limitations for deeper intervention in the civil society. at the grass roots level. The COVID-19 Prevention Task Force was divided into four task forces, namely the Wani Jogo Task Force, Wani Ngandani Task Force, Wani Sehat Task Force, and Wani Sejahtera Task Force, which had their respective roles. Implementatively, all elements move together to work together to break the chain of the spread of COVID19.

Several obstacles were encountered, such as lack of funds and low public awareness. There were still many people who think that the coronavirus did not exist, it was just a conspiracy and was in the interests of capitalists as if it was deliberately made up. Even though public awareness was urgently needed to stop the spread of COVID-19. Therefore, it is suggested that a persuasive, educational and regulatory approach should be carried out massively. In addition, even though the funds were minimal, in fact, it did not diminish the enthusiasm of the civil society, the need for funds is collected independently (jointly) and assisted by donors.

\section{ACKNOWLEDGMENTS}

This study is the result of the COVID19 Community Service Program (KKN) of "Universitas Pembangunan Nasional "Veteran" East Java in Sidoklumpuk Village, Sidoarjo Sub-District, Sidoarjo Regency. We would like to express our gratitude and the highest appreciation to the people of Sidoklumpuk Village, especially the Sidoklumpuk Village Headman, the Secretary of the Sidoklumpuk Village, and the Empowerment of Family Welfare (PKK) Sidoklumpuk Village who gave us the opportunity to do this study.

\section{BIBLIOGRAPHY}

Ariyanto, B. (2020). Management of Inter-Central and Regional Relations in Handling the COVID-19 Pandemic. Suloh Journal of the Malikussaleh University Law Masters Study Program, 8 (2), 37-57.

Aslichati, L., Prasetyo, B., \& Irawan, P. (2017). Social Research Methods (1st ed.). Open University.

National Board for Disaster Management. (2020). The Most Rational Choice of PSBB Policy in the Middle of Covid-19. https://bnpb.go.id/berita/keb Policy-psbbpilih-paling-rasional-di-tengah-covid19

Djalante, R., Lassa, J., Setiamarga, D., Sudjatma, A., Indrawan, M., Haryanto, B., Mahfud, C., Sinapoy, MS, Djalante, S., Rafliana, I., Gunawan , LA, Surtiari, GAK, \& Warsilah, H. (2020). Review and Analysis of Current Responses to COVID-19 in Indonesia: Period of January to March 2020. Progress in Disaster Science, 6 (100091), 1-9. https://doi.org/http://dx.doi.org/10.1016/j. pdisas.2020.100091

Johns Hopkins University (JHU). (2020). COVID-19 Update. COVID-19 Dashboard by the Center for Systems Science and Engineering (CSSE) at Johns Hopkins University (JHU). https://gisanddata.maps.arcgis.com/apps/o psdashboard/index.html\#/bda7594740fd40 299423467b48e9ecf6

Ministry of Health of the Republic of Indonesia. (2020). Five Treatment Protocols Become Main Guidelines for Preventing and Controlling COVID-19. https://covid19.kemkes.go.id/situasi-infemerging/info-corona-virus/lima-protokolpanganan-jadi-pedoman-utama- preventdan-kontrol-covid-19/\#.XyUG9pYzbIV

Kompas.com. (2020a). The Government Claims that the Percentage of Deaths Due to Covid-19 in Indonesia is Lower than Japan. https://nasional.kompas.com/read/2020/0 6/29/17011651/pemerintah-klaimperscent-kematian-akibat-covid-19-diindonesia-lmore

Kompas.com. (2020b). Minister of Health Terawan's Controversial Statement at the Beginning of the Covid-19 Pandemic. https://nasional.kompas.com/read/2020/0 9/29/16290701/perlasi-kontroversialmenkes-terawan-di-awal-pandemi-covid19?page $=$ all

Kompas.com. (2020c). WHO Announces Coronavirus Outbreak Has Global Emergency Status, What Does It Mean? https://sains.kompas.com/read/2020/01/3 1/113000623/who- announced-wabahvirus-corona-berstatus-darurat-global-apaartinya?page $=$ all 
Kuswana, D. (2011). Social Research Methods (BA Saebani (ed.); 1st ed.). CV. Faithful Library.

Mardikanto, Totok and Soebiato, P. (2012). Civil society Empowerment in Public Policy Perspective. CV. Alfabeta.

Mas'udi, W., \& Winanti, PS (2020). Governance for Handling COVID-19 in Indonesia: Initial Assessment (1st ed.). Gadjah Mada University Press. https://digitalpress.ugm.ac.id/book/257

Miles, MB, Huberman, AM, \& Saldana, J. (2014). Qualitative Data Analysis: A Methods Sourcebook (3rd ed.). SAGE Publication, Inc.

Mulyadi, M. (2020). Civil society Participation in Handling the Spread of Covid-19. Research Center for the DPR RI Research Institute, XII (8), 13-18.

Pasaribu J. (2012). Development Theory and Content. UM Press.

Sidoarjo Regency Government. (2020a). Sidoarjo regency continues to echo the fight against the Covid-19 pandemic. http://portal.sidoarjokab.go.id/pemkabsidoarjo-terus-dengung-perangi-pandemicovid-19

Sidoarjo Regency Government. (2020b). Sidoarjo Regency Government Team Distributes Masks and Forms of the Covid-19 Command Post. http://portal.sidoarjokab.go.id/timpemkab-sidoarjo-memb Bagi-masker-danbentuk-posko-covid-19

Purnomo, S. (2020). Against Covid-19, Sidoarjo Launches Kampung Tangguh Semeru. https://rmoljatim.id/2020/05/27/lawancovid-19-sidoarjo-l Launch-kampungtangguh-semeru/
Sastropoetro, S. (1986). Participation, Communication, Persuasion and Discipline in National Development. PT. Alumni.

Sugiyono. (2019). Quantitative Research Methods, Qualitative, and R \& D (2nd ed.). CV Alfabeta.

Surabaya Morning. (2020). Tangguh Village Becomes a National Icon. http://surabayapagi.com/read/kampungtangguh-jadi-icon-nasional

Suryahadi, A., Al Izzati, R., \& Suryadarma, D. (2020). The Impact of COVID-19 Outbreak on Poverty: An Estimation for Indonesia. In SMERU Working Paper: Vol. April. The Semeru Research Institute. http://smeru.or.id/en/content/impactcovid-19-outbreak-poverty-estimationindonesia

Viva.co.id. (2020). Judged as Lightly Corona, \#CopotMenkesTerawan Emerged. https://www.viva.co.id/berita/nasional/126 7870-dinilai-anggap-enteng-coronacopotmenkesterawan-mengunjuk

WHO. (2020). Rolling updates on coronavirus disease (COVID-19) Updated 17 June 2020. Coronavirus (COVID-19) Events as They Happen.

https://www.who.int/emergencies/diseases /novel-coronavirus-2019/events-as-theyhappen

Wijaksono, S. (2013). Effect of Length of Stay in the Management of the Residential Environment. BINUS ComTech Journal, 4 (1), 24-32. https://doi.org/10.21512/comtech.v4i1.267 9 